\section{Enhancing, not cheating}

\section{A broad debate about the use of drugs that improve cognition for both the healthy and the ill is needed.}

O $\mathrm{f}$ all the arguments levelled against taking drugs for human enhancement, the idea that it is cheating has least power. Yes, when organized competition or formal testing of abilities is the name of the game, drug-based strengthening is questionable and regulations against it need to be adhered to.

More debatable are arguments by opponents of drug-based enhancement that it is cheating against oneself. "Personal achievements impersonally achieved are not truly the achievements of persons," said the report Beyond Therapy by the US President's Council on Bioethics, chaired at the time by ethicist Leon Kass. Yet imagine if a researcher could improve his or her ability to memorize the postulated connections in a complex signalling pathway central to tumour development, or if a musician could improve his or her concentration and deliver a better performance on the night. Far from cheating on themselves or others, they would be delivering a higher return on their investment of effort, and indeed on society's investment in them. We all benefit.

What is sure is that opponents of enhancement are, to a degree, whistling in the wind. They raise other spectres - unfairness of access (although today's enhancing dose is cheaper than a cup of coffee), possibilities of employer coercion and the loss of human dignity or of the 'natural' - but ultimately, to little avail. Many healthy people still opt for chemical enhancements of all sorts, as suppliers of cosmetics and some pharmaceuticals know well. Such actions betoken an ethical argument on the other side: the pursuit of personal liberty.

\section{Prescription for change}

\author{
Health research in Italy is in desperate \\ need of a fresh start.
}

\rceil hese are painful times for Livia Turco, the Italian health minister. A member of the centre-left Democratic Party, Turco has been caught in a web of power politics that has led her to nominate Enrico Garaci to serve a third term as president of the ISS, an important, publicly funded health-research institute in Rome. The nomination is seen by many as problematic because Garaci has not fully embraced the open and competitive peer review that Italian research policy must adopt if it is to compete more effectively with other scientific powers of comparable size.

On 6 November, the Italian Senate's health committee took the unusual move of rejecting the nomination. Legally, Turco is obliged to take note of the Senate's view - and also that of the chamber of deputies, a committee of which approved the nomination on 24 October - but she does not have to follow it. By withdrawing the nomination, she may lose political face, but by insisting on it, she will undermine her government's main objective, which is to cajole Italian governance into a new era of meritocracy and openness.
Studies on healthy volunteers have shown the cognitive effects of enhancing drugs to be mild, but sufficient to be considered helpful. The pills with least risky side effects seem to be methylphenidate (prescribed for attention-deficit disorder) and modafinil (prescribed for narcolepsy). Studies, mostly in the United States, have documented usage of drugs for cognitive enhancement by $5-15 \%$ of students, and anecdotes abound of use by postdocs and academics.

As described in a valuable discus-

\section{"Studies have documented usage of drugs for cognitive enhancement by $5-15 \%$ of students."}

sion paper from the British Medical Association (www.bma.org.uk/ ap.nsf/Content/CognitiveEnhancement2007), these drugs have an honourable track record in helping the afflicted - and they could do yet more to that end. The risks of long-term use are not well understood (although that also applies to many approved drug therapies). And the ethical issues are not to be ignored, although the document lacks a description of who stands to make money from enhancement drugs. Appropriately, it reviews the issues and sets out topics for debate, rather than advocating use or restriction of enhancers.

The debate itself is not new, but it has been confined to relatively small circles. Yet the use of cognitive-enhancing drugs by both the ill and the healthy - and those in the substantial grey zone overlapping both - is already more widespread than is generally appreciated. The lack of debate on regulation by nations or by institutions, such as universities, is increasingly problematic. And those in favour of chemically induced cognitive enhancement for the healthy need to develop their scientific and ethical case, because it will be all too easy for the ethically conservative to hold sway over political leaders, most of whom would prefer to wish this particular challenge away.

The ISS is in some ways Italy's equivalent of the Pasteur Institute in Paris. It employs around 1,500 scientists who work in areas such as vaccines, stem cells and genomics, and its $€ 100$ million (US\$145 million) annual budget is mostly absorbed by salaries - although the institute also coordinates some extramural projects.

The way in which Garaci has administered these projects has often upset other senior scientists. Their discontent is currently focused on $€ 3$ million allocated to stem-cell research this year. Stem-cell researchers have complained to Turco in a letter to which she has not replied. Newspapers have pointed out that Garaci was a member of the health-ministry committee that helped decide that the ISS would distribute the stem-cell funds. Moreover critics fear that Garaci's own doctrinaire brand of Catholicism - he is a member of the conservative Science and Life group - may prevent the small programme from supporting work that would be permitted under the law, but of which he may personally disapprove.

On balance, Garaci lacks the confidence among his peers that a director of the ISS needs. Turco should withdraw his nomination and follow the procedure adopted successfully by her colleague, research minister Fabio Mussi, in filling top positions. She should set up an independent search committee to draw up a shortlist of candidates from which she can select a nominee, who would then have the full confidence of Italy's biomedical research community. 